\title{
ANALISIS KELAYAKAN DOLAR AMERIKA, EURO, DAN DINAR EMAS DALAM KONVERSI DOLAR AMERIKA SEBAGAI ALAT LINDUNG NILAI DENGAN EMAS SEBAGAI ALAT UKUR DALAM LAPORAN KEUANGAN
}

\author{
Oleh : \\ Praditya Dewi Arumsari \\ Ayu Noviani Hanum \\ Program Studi Akuntansi \\ Fakultas Ekonomi \\ Universitas Muhammadiyah Semarang
}

\begin{abstract}
:
For this study was to analyze the potential of the Gold Dinar as a hedging tool replaces the U.S. Dollar. U.S. Dollar in recent year experienced extreme exchange rate movements so that researchers analyzed the stability of the current compared to Euro that threatening position U.S. Dollar as the world's major currencies. Stable currency has the accuracy and reliability in an accounting information to make decisions of an organization or company. The data used in this study is secondary data by type of time series. Monthly data from 2003 antil 2012. To determine the stability of each currency, the data obtained should be free from containt of the unit root, has a normal distributed, and constant. The volatility calculation of 0.0408792 (Gold Dinar), 0.0408790 (U.S. Dollar), and 0.040540 (Euro). Volatility is a statiscal measure of the diversion returns for a given security. From the research that has been done, calculation of the Euro states have a low risk of change in value and have a steady rate. With that result, Euro can be reference currency in financial reporting.
\end{abstract}

Keywords: Hedging, U.S. Dollar, Euro, Gold Dinar, Gold, Accounting Information, Financial Reporting. 


\section{PENDAHULUAN}

Pesatnya laju perkembangan dunia teknologi dan informasi, menyebabkan perkembangan pada pasar keuangan dunia tidak dapat dihindari. Hal ini menjadi pemicu meningkatnya resiko yang akan dihadapi para investor. Diversifikasi portofolio internasional yang biasanya dipakai para investor hanya dapat mengurangi risiko non-systematic dan belum dapat mengurangi risiko pasar. Untuk itulah diperlukan lindung nilai untuk mengurangi resiko pasar yang dapat menurunkan tingkat varians return. Hal ini dapat dilakukan dengan menambahkan kontrak derivative sebagai instrumen lindung nilai (hedging). Lindung nilai atau hedging adalah suatu tindakan yang diambil oleh perusahaan untuk melindungi perusahaan terhadap pergerakan nilai tukar.

Mekanisme hedging merupakan transaksi derivatif berupa transaksi sistem lindung nilai komoditi terhadap volatilitas pasar. Lindung nilai yang sempurna adalah dengan mengeleminasi semua risiko, namun perfect hedging merupakan hal yang sangat jarang sekali adanya. Dengan menggunakan kontrak derivative diharapkan dapat mendekatkan pada kondisi lindung nilai yang sesempurna mungkin. Sehingga, nantinya diharapkan imbal hasil yang diperoleh dapat sesuai dengan imbal hasil yang telah diperkirakan (Hull, 2008:25). Peraturan tentang lindung nilai sendiri telah ada dan tercantum pada PSAK No. 55 (Revisi 2006) Instrumen Keuangan: Pengakuan dan Pengukuran. Pada PSAK No. 55 ini tercantum berbagai macam penjelasan tentang instrumen derivatif dan lindung nilai yang telah beberapa kali direvisi dengan revisi terakhir tahun 2006.

Dalam penerapannya, lindung nilai dapat dibedakan menjadi 2 (dua), Short Hedging dan Long Hedging. Short hedging adalah lindung nilai yang memiliki posisi pendek (short position) dalam kontrak berjangka. Short hedges dikatakan sesuai bila hedger telah memiliki aset sendiri dan mengharapkan dapat menjual pada suatu waktu yang akan datang. Short hedges merupakan ketepatan dari hedger yang telah memiliki sejumlah aset dan akan menjual aset tersebut di masa yang akan datang dengan harga yang telah pasti (Hull, 2008:47).

Short hedges juga dapat digunakan untuk aset yang tidak dimiliki pada saat ini, namun akan dimiliki pada suatu waktu dimasa yang akan datang. Sebagai contoh seoarang eksportir yang akan menerima dolar pada 5 (lima) bulan kedepan. Eksportir akan merealisasikan keuntungan jika nilai dolar menguat relatif terhadap rupiah. Posisi short futures akan menyebabkan kerugian jika nilai dolar mengalami penguatan dan memperoleh keuntungan jika nilai dolar mengalami penurunan.

Sedangkan Long Hedging merupakan lindung nilai dimana posisi panjang diambil dalam kontrak berjangka. Suatu long hedging dikatakan tepat apabila perusahaan tahu bahwa ia harus memiliki aset tertentu dikemudian hari dan menutup harga sekarang. Maksudnya adalah jika perusahaan berencana membeli saham dimasa yang akan datang, tetapi perusahaan ingin memastikan harganya, maka perusahaan tersebut harus mengambil kontrak beli di masa yang akan datang. Sehingga, berapapun harga yang diperoleh pada saat jatuh tempo, perusahaan akan tetap membeli saham sesuai dengan harga yang telah ditetapkan sebelumnya (Hull, 2008:47).

Selama ini, hedging atau lindung nilai menggunakan acuan ukur mata uang Dolar Amerika. Sebagian orang beranggapan Dolar Amerika merupakan mata uang yang paling stabil. Tetapi beberapa tahun terakhir ini, Dolar Amerika mengalami kenaikan dan penurunan yang berubah tiap harinya. Dengan penurunan mata uang Dolar Amerika tersebut, ada wacana tentang mengganti mata uang Dolar Amerika sebagai acuan dengan menggunakan mata uang Euro yang disebut -sebut lebih stabil sekarang ini 
daripada mata uang Dolar Amerika. Dengan penciptaan European Monetary System dan Euro pada 1999, mata uang Dolar Amerika menghadapi suatu tantangan atas posisinya sebagai mata uang utama dalam transaksi keuangan internasional (Mishkin, 2008:151). Sejak digunakan secara luas pertama kali pada 1 Januari 2002, mata uang Euro terus menunjukkan stabilitas dan mengalami penguatan terhadap mata uang Dolar Amerika hampir 12\%. Meskipun dalam beberapa bulan mata uang Euro mengalami penguatan, hal ini belum bisa dijadikan indikasi bahwa mata uang Euro stabil.

Alternatif alat lindung nilai lain selain mata uang Dolar Amerika dan mata uang Euro yang sudah dipastikan stabil adalah emas. Emas adalah investasi yang tepat sebagai sarana lindung nilai, dari tahun ke tahun nilainya stabil dan cenderung mengalami peningkatan. Alat lindung nilai dalam emas yang sudah ada pada jaman Rasulullah dalam bentuk Dinar Emas. Iqbal (2009) menjelaskan bahwa Dinar Emas adalah emas murni 22 karat dengan berat 4,25 gram.

Pengertian akuntansi menurut American Accounting Association adalah Accounting as the process identifying, measuring, and communicating economic information to permit informed judgements and decisions by users of the information. Informasi ekonomi adalah informasi yang berkaitan dengan berbagai situasi yang melibatkan keterbatasan sumber daya. Proses akuntansi ini diakhiri dengan tersedianya laporan keuangan (en.wikipedia.org).

Belkaoui (2000) mendefinisikan informasi akuntansi sebagai informasi kuantitatif tentang entitas ekonomi yang bermanfaat untuk pengambilan keputusan ekonomi dalam menentukan pilihan pilihan diantara alternatif - alternatif tindakan. Penggunaan informasi akuntansi tersebut untuk perencanaan strategis, pengawasan manajemen dan pengawasan operasional (Sulfa, 2009:3).
Informasi akuntansi pada dasarnya bersifat keuangan dan terutama digunakan untuk tujuan pengambilan keputusan, pengawasan, dan implementasi keputusan - keputusan perusahaan (Arnold and Hope, 1990). Agar data keuangan dapat dimanfaatkan dengan baik oleh pihak internal maupun eksternal perusahaan, maka data tersebut harus disusun dalam bentuk - bentuk yang sesuai (Sulfa, 2009:3).

Peneliti memilih meneliti tentang lindung nilai atau hedging karena semakin pesatnya pasar keuangan dunia dan melihat ketidakstabilan mata uang Dolar Amerika beberapa tahun terakhir. Sedangkan alasan memilih Dinar Emas dikarenakan trend investasi dan berkembangnya Dinar Emas mulai dirasakan di Indonesia. Pada akhir penelitian dapat dilihat apakah Dinar Emas cukup layak dijadikan acuan alat hedging pengganti Dolar Amerika. Maka dalam penelitian ini, peneliti akan memilih judul, "Analisis Kelayakan Dolar Amerika, Euro, dan Dinar Emas Dalam Konversi Dolar Amerika Sebagai Alat Lindung Nilai dengan Emas Sebagai Alat Ukur Dalam Laporan Keuangan".

\section{Rumusan Masalah}

Berdasarkan latar belakang dapat dirumuskan beberapa perumusan masalah, yaitu:

1. Apakah mata uang Dolar Amerika sebagai lindung nilai lebih baik dibandingkan dengan mata uang Euro ?

2. Apakah Dinar Emas sebagai lindung nilai lebih baik dibandingkan dengan mata uang Dolar Amerika ?

3. Apakah mata uang Dolar Amerika dan mata uang Euro lebih stabil dibandingkan dengan Dinar Emas?

4. Apakah mata uang Dolar Amerika dan mata uang Euro lebih stabil dibandingkan dengan Dinar Emas sebagai Informasi Akuntansi ? 


\section{Tujuan Penelitian}

1. Menganalisis potensi Dinar Emas sebagai acuan utama dalam transaksi lindung nilai.

2. Menganalisis kestabilan mata uang Dolar Amerika sebagai mata uang utama dalam transaksi keuangan internasional saat ini.

3. Menganalisis kestabilan mata uang Euro sebagai pesaing mata uang Dolar Amerika sebagai mata uang utama dalam transaksi keuangan internasional.

4. Menganalisis keakuratan dan kehandalan antara mata uang Dolar Amerika, Euro, dan Dinar Emas dalam suatu laporan keuangan.

Dari beberapa penelitian yang telah dilakukan sebelumnya, ada beberapa hasil penelitian yang mempunyai kesimpulan yang sama. Kesimpulan tersebut menyatakan bahwa emas memiliki nilai yang stabil. Emas juga merupakan investasi yang paling menguntungkan. Karena jika menggunakan emas, nilainya akan terus bertambah dan kenaikannya selalu stabil.
Bentuk investasi emas yang disarankan berupa koin Dinar Emas. Dinar Emas pernah digunakan sebagai alat tukar pada jaman Rasulullah S.A.W. Tetapi seiring berjalannya waktu dan pengaruh dari beberapa negara adidaya, koin Dinar Emas atau emas itu sendiri mulai tidak digunakan sebagai alat tukar dengan alasan persediaan emas dunia yang semakin menipis.

Ditemukan juga hasil penelitian yang menyatakan mata uang Euro memiliki risiko yang lebih kecil dibandingkan dengan menggunakan Dolar Amerika dan Rupiah. Euro juga merupakan mata uang yang paling stabil saat ini. Jadi, Euro bisa dijadikan alternatif alat tukar utama dalam perdagangan internasional. Hal ini dikarenakan mata uang acuan utama yaitu Dolar Amerika mengalami ketidakstabilan selama beberapa tahun terakhir.

Untuk itu, agar meminimalisir risiko akibat fluktuasi mata uang digunakan lindung nilai. Sebagian besar penelitian menyatakan, emas lebih baik dalam melindungi nilai. Untuk membuktikan pernyataan tersebut, dilakukanlah penelitian ini dengan menggunakan obyek penelitian Dolar Amerika, Euro, dan Dinar Emas

\section{Kerangka Penelitian}

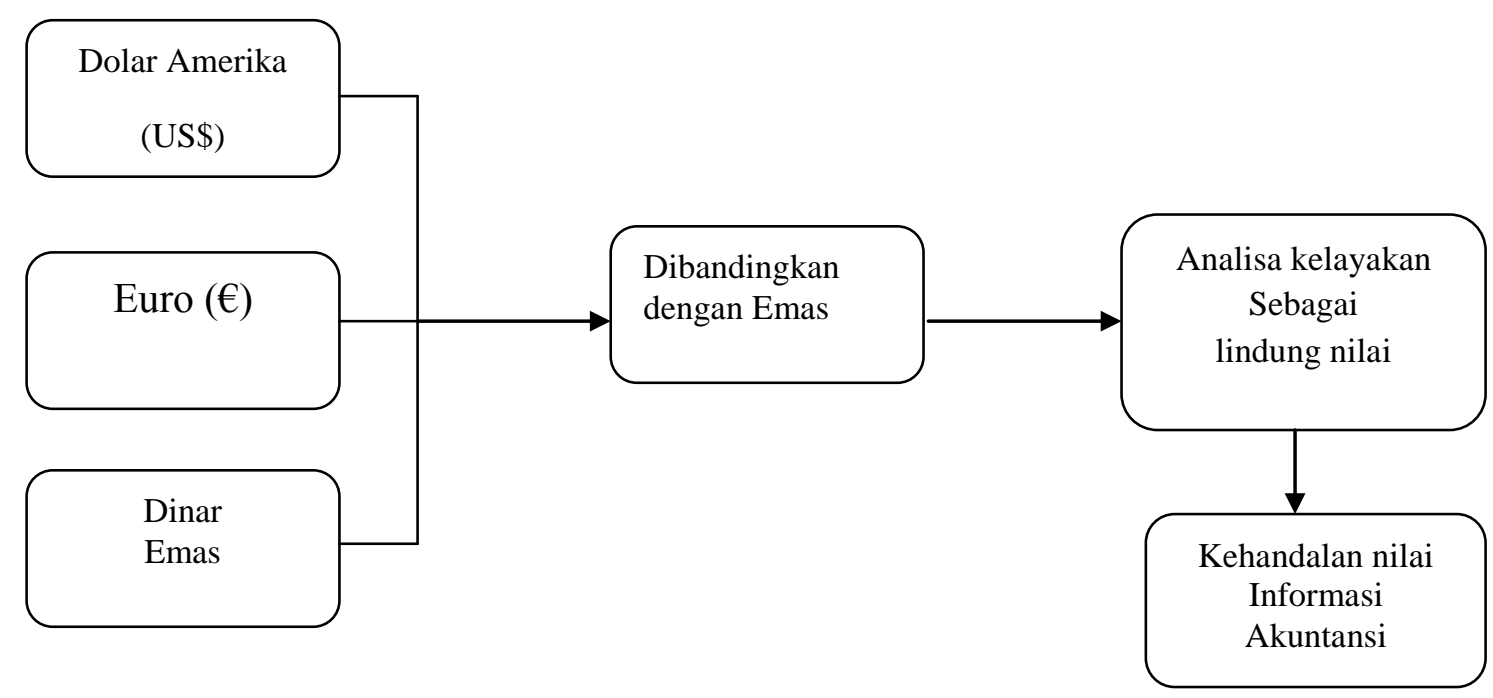




\section{Perumusan Hipotesis}

1. $\mathrm{Ho}_{1}$ : Mata uang Dolar Amerika sebagai lindung nilai lebih baik hasilnya dibandingkan dengan mata uang Euro.

$\mathrm{Ha}_{1} \quad$ : Mata uang Dolar Amerika sebagai lindung nilai tidak lebih baik hasilnya dibandingkan dengan mata uang Euro.

2. $\mathrm{Ho}_{2}$ : Dinar Emas sebagai lindung nilai lebih baik hasilnya dibandingkan dengan mata uang Dolar Amerika.

$\mathrm{Ha}_{2}$ : Dinar Emas sebagai lindung nilai tidak lebih baik

\section{METODE PENELITIAN}

Dalam penelitian ini variabel yang digunakan adalah Dolar Amerika, Euro, dan Dinar Emas dikonversikan ke dalam mata uang Dolar Amerika. Sebelum dikonversikan ke dalam Dolar Amerika, dicari harga emas per troy ounce dalam masing - masing mata uang. Dolar Amerika digunakan karena merupakan mata uang acuan utama dalam perdagangan internasional. Sedangkan mata uang Euro digunakan karena merupakan mata uang dengan pengaruh terkuat setelah Dolar Amerika. Ini dibuktikan dengan meningkatnya popularitas Euro dari 16,3\% di komposisi sirkulasi uang dunia pada tahun 2000 menjadi $19,7 \%$ dalam kurun waktu 3 tahun yaitu tahun 2003 (Hamidi, 2007:3). Penggunaan Dinar Emas sebagai variabel penelitian disebabkan karena semakin banyak penelitian tentang kembalinya penggunaan Dinar Emas yang mempunyai nilai intrinsik sehingga nilainya tetap stabil walaupun setelah beberapa dekade.

Dalam penelitian ini, interval data yang digunakan adalah data bulanan dalam jangka waktu 10 tahun sejak tahun 2003 sampai tahun 2012. Data - data tersebut adalah : hasilnya dibandingkan dengan mata uang Dolar Amerika.

3. $\mathrm{Ho}_{3}$ : mata uang Dolar Amerika dan mata uang Euro lebih stabil dibandingkan dengan Dinar Emas.

$\mathrm{Ha}_{3}$ : mata uang Dolar Amerika dan mata uang Euro tidak lebih stabil dibandingkan dengan Dinar Emas.

4. $\mathrm{Ho}_{4}$ : mata uang Dolar Amerika dan mata uang Euro lebih handal dibandingkan dengan Dinar Emas dalam Informasi Akuntansi.

$\mathrm{Ha}_{4} \quad$ : mata uang Dolar Amerika dan mata uang Euro tidak lebih handal dibandingkan dengan Dinar Emas dalam Informasi Akuntansi.

a. Data rata - rata bulanan.

b. Data fluktuasi kurs mata uang Dolar Amerika dan mata uang Euro.

c. Data Indeks Harga Konsumen (IHK). Untuk mendapatkan nilai tukar emas yang riil, harga emas dibagi dengan IHK.

d. Data harga emas dikalikan nilai tukar Dolar Amerika. Untuk mendapatkan harga Dinar Emas, harga emas dikalikan dengan 0,137 yang diperoleh dari pembagian jumlah gram emas untuk mendapat satu dinar emas yang setara dengan 4,25 gram emas dengan jumlah emas dalam ukuran 1 ounce $(31,1$ gram). Hasil yang diperoleh dari perkalian tersebut masih dalam nilai emas 24 karat. Sedangkan nilai 1 Dinar Emas setara dengan emas 22 karat 4,25 gram. Untuk mengkonversi Dinar Emas yang mempunyai nilai intrinsik 22 karat, hasil tersebut dikalikan lagi dengan 0,917 .

Setelah melakukan pengumpulan data, langkah selanjutnya dalam penelitian ini adalah menganalisis dan mengolah data. Untuk mendapatkan hasil penelitian yang diinginkan, langkah awal yang harus dilakukan adalah screening terhadap 
normalitas data yang telah terkumpul. Selanjutnya dilakukan uji heteroskedastisitas untuk menguji ketidaksamaan varians dari residual satu pengamatan ke pengamatan lain. Dan langkah akhir penelitian dilakukan uji ANOVA untuk mengetahui rata - rata data berbeda atau tidak. Lalu untuk mengetahui stabilitas Dolar Amerika, Euro, dan Dinar Emas dilakukan uji Variance.

a. Perhitungan Return

Sebelum menguji normalitas data dan untuk mempermudah perhitungan data - data, hal yang pertama kali dilakukan adalah menghitung return. Karakteristik data historis spot rate akan dapat diketahui dari pengamatan. Data yang diamati memiliki rentang waktu yang panjang, maka untuk pengukuran dilakukan secara geometricreturn (Jorion, 2001:99). Perhitungan return dapat dilakukan menggunakan Microsoft Excel.

b. Uji Stasioneritas

Uji Stasioneritas dilakukan untuk mengetahui apakah data return sudah stasioner. Pengujian data ini menggunakan $A D F$ test yang bertujuan untuk mengetahui data return masih mengandung unit root atau tidak. Jika hasil uji data ini menunjukkan data return masih mengandung unit root maka dapat disimpulkan data return belum stasioner. Tetapi jika hasil menyatakan data return sudah tidak mengandung unit root, maka data return stasioner. Data return yang sudah stasioner selanjutnya dapat digunakan dalam pengujian selanjutnya. Sedangkan data yang belum stasioner dilakukan differencing hingga data stasioner. Untuk menentukan sudah stasioner atau belum suatu data dapat dilakukan dengan membandingkan $A D F$ Test dengan critical value. Jika nilai $A D F$ Test lebih kecil dari critical value atau memiliki probabilitas lebih kecil dari 5\% maka data tersebut sudah stasioner. Begitu juga sebaliknya, jika $A D F$ Test nilainya lebih besar dari critical value atau memiliki probabilitas yang lebih besar dari 5\% maka data tersebut belum stasioner dan harus dilakukan differencing hingga $A D F$ Test nya lebih kecil dari critical value.

c. Uji Normalitas

Uji normalitas ini bertujuan untuk menguji apakah data return memiliki distribusi normal atau tidak. Secara statistik, ada dua komponen normalitas yaitu Skewness dan Kurtosis. Skewness berhubungan dengan tingkat kemiringan dan Kurtosis berhubungan dengan puncak suatu distribusi. Jika data return terdistribusi secara normal maka nilai Skewness dan Kurtosis sama dengan nol. Uji normalitas ini menggunakan Eviews 6. Jika nilai Jarque Bera lebih besar dari critical value atau mempunyai probabilitas lebih kecil daripada 5\% maka diperoleh kesimpulan bahwa return yang dihasilkan tidak mengikuti distribusi normal. Tetapi jika nilai Jarque Bera lebih kecil dari critical value atau probabilitasnya lebih besar dari 5\% maka kesimpulannya data terdistribusi secara normal.

d. Uji Heteroskedastisitas

Uji Heteroskedasitisitas bertujuan untuk menguji apakah data return terjadi ketidaksamaan varians. Jika varians data return tetap disebut Homoskedastisitas dan jika berbeda disebut Heteroskedastisitas. Data yang baik adalah data yang Homoskedastisitas dan tidak terjadi Heteroskedastisitas. Kebanyakan data crossection mengandung situasi heteroskedastisitas karena 
data ini menghimpun data yang mewakili berbagai ukuran. Apabila angka probabilitas lebih kecil dari 5\% maka dapat disimpulkan bahwa data return bersifat heteroskedastisitas. Tetapi sebaliknya, jika angka probabilitas lebih besar dari 5\% dapat disimpulkan bahwa data bersifat homoskedastisitas. Apabila diperoleh hasil heteroskedastisitas maka hasil tersebut harus dikoreksi hingga mendapatkan hasil yang bersifat homoskedastisitas. Salah satunya menggunakan model AutoRegressive Conditional Heteroskedasticity (ARCH).

e. Analysis of Variance

ANOVA adalah salah satu cara yang digunakan untuk menguji kestabilan variabel yang digunakan. ANOVA digunakan juga untuk mengetahui pengaruh utama dan pengaruh interaksi dari variabel independen kategorikal terhadap variabel dependen metrik (Ghazali, 2011:68). ANOVA dikelompokkan menjadi dua, yaitu:

1. Hubungan antara satu variabel dependen dengan satu variabel independen disebut dengan One Way ANOVA.

2. Hubungan antara satu variabel dependen metrik dan dua variabel independen kategorikal disebut Two Ways ANOVA dan hubungan antara satu variabel dependen metrik dengan tiga variabel independen kategorikal disebut Three Ways ANOVA.

\section{HASIL DAN PEMBAHASAN}

Tahap awal pengujian data dengan total data berjumlah 120, yang diperoleh dari tahun 2003 - 2012 setiap bulannya adalah dengan menghitung return. Menghitung return data dilakukan untuk setiap bulannya. Misal diketahui rata - rata harga emas per troy ounce dalam Dolar Amerika bulan Januari 2007 sebesar \$630,024 dan rata - rata pada bulan Februari 2007 adalah $\$ 665,147$, maka perhitungan return untuk Dolar Amerika adalah adalah:

$$
\begin{aligned}
\text { Return }_{\text {Februari }} & =\ln (665,147 / 630,024) \\
& =0,0543
\end{aligned}
$$
data mentah dihitung return setiap bulannya, dengan menggunakan ADF Test (unit root test) pada software Eviews6 diperoleh hasil:

Tabel 1. Hasil Uji Stasioneritas

\begin{tabular}{|l|c|c|c|}
\hline \multicolumn{1}{|c|}{$\begin{array}{c}\text { Data } \\
\text { Return }\end{array}$} & $\begin{array}{c}\text { Hasil } \\
\text { ADF } \\
\text { Test }\end{array}$ & $\begin{array}{c}\text { CV (level } \\
\mathbf{5 \%})\end{array}$ & Probabilitas \\
\hline $\begin{array}{l}\text { Dolar } \\
\text { Amerika }\end{array}$ & $\begin{array}{c}- \\
10,85214\end{array}$ & $\begin{array}{c}- \\
2,885863\end{array}$ & 0,0000 \\
\hline Euro & $\begin{array}{c}- \\
-\end{array}$ & 0,0000 \\
\hline $\begin{array}{l}\text { Dinar } \\
\text { Emas }\end{array}$ & $\begin{array}{c}- \\
10,73682\end{array}$ & $\begin{array}{c}- \\
-\end{array}$ & 0,0000 \\
\hline
\end{tabular}

Sumber: www.oanda.com, data diolah.

Dari tabel diatas, dapat diketahui bahwa semua data return (Dolar Amerika, Euro, dan Dinar Emas) memperoleh hasil ADF Test yang lebih kecil dari critical value. Maka kesimpulan yang diperoleh adalah ketiga data return stasioner.

Sedangkan pada uji normalitas, diketahui dari hasil uji bahwa ketiga data return mempunyai nilai probabilitas diatas 5\%. Artinya, semua data return terdistrubusi secara normal, seperti pada tabel 
Tabel 2. Hasil Uji Normalitas

\begin{tabular}{|l|r|r|r|r|}
\hline Data Return & Jarque Bera & $\begin{array}{c}\text { Chi Square } \\
\boldsymbol{\alpha}=\mathbf{5 \% , d f = 2}\end{array}$ & Probabilitas & Pola Distribusi \\
\hline Dolar AS & 4,066495 & 5,99147 & 0,130910 & Normal \\
\hline Euro & 4,504789 & 5,99147 & 0,105147 & Normal \\
\hline Dinar Emas & 4,067280 & 5,99147 & 0,130858 & Normal \\
\hline
\end{tabular}

Sumber: www.oanda.com, data diolah

Pada uji heteroskedastisitas, peneliti menggunakan white heteroskedasticity test pada Eviews6. Untuk melihat data return bersifat konstan atau tidak. darin penelitian yang telah dilakukan, nilai F-statistik probabilitas ketiga data return mempunyai nilai yang lebih besar dari 0,05. Maka didapat kesimpulan bahwa data return bersifat time varying atau homoskedastisitas, berikut hasil penelitiannya
Tabel 3. Hasil Uji Heteroskedastisitas

\begin{tabular}{|l|r|r|}
\hline Data Return & F-Statistik & Probabilitas \\
\hline Dolar Amerika & 2,933053 & 0,057194 \\
\hline Euro & 2,777664 & 0,066324 \\
\hline Dinar Emas & 2,777879 & 0,066311 \\
\hline
\end{tabular}

Sumber: www.oanda.com, data diolah

Dari pengujian regresi dengan uji ANOVA, dapat diketahui bahwa $p$ value sebesar $0,000<$ dari $\alpha=0,05$ (F $F_{\text {hitung }}$ sebesar 242,719 lebih besar dibandingkan dengan $F$ tabel sebesar 2,68). Sehingga dapat disimpulkan bahwa Dolar Amerika, Euro, dan Dinar berpengaruh terhadap Emas.

Untuk melihat kestabilan mata uang Dolar Amerika, mata uang Euro, dan Dinar Emas, dilakukan dengan menghitung standar deviasi perbulan tiap mata uang dan Dinar Emas.

Tabel 4.6. Standar Deviasi Dolar Amerika, Euro, dan Dinar Emas

\begin{tabular}{|c|r|r|r|}
\hline \multirow{2}{*}{$\begin{array}{c}\text { Emas per OZ } \\
\text { (XAU) }\end{array}$} & \multicolumn{3}{|c|}{ Standar Deviasi } \\
\cline { 2 - 4 } & Dolar Amerika & Euro & Dinar Emas \\
\hline 2003 & 0,039860 & 0,039861 & 0,039860 \\
\hline 2004 & 0,030809 & 0,030720 & 0,030808 \\
\hline 2005 & 0,032527 & 0,029327 & 0,032528 \\
\hline 2006 & 0,063720 & 0,063784 & 0,063720 \\
\hline 2007 & 0,034226 & 0,034211 & 0,034224 \\
\hline 2008 & 0,063162 & 0,063174 & 0,063162 \\
\hline 2009 & 0,037580 & 0,037580 & 0,037580 \\
\hline 2010 & 0,026786 & 0,026725 & 0,026786 \\
\hline 2011 & 0,047814 & 0,047726 & 0,047815 \\
\hline 2012 & 0,032309 & 0,032291 & 0,032309 \\
\hline Rata - Rata & $\mathbf{0 , 0 4 0 8 7 9 0}$ & $\mathbf{0 , 0 4 0 5 4}$ & $\mathbf{0 , 0 4 0 8 7 9 2}$ \\
\hline
\end{tabular}

Berdasarkan tabel diatas, diketahui rata -rata votalitas tiap mata uang sehingga analisisnya adalah nilai terendah dan tertinggi ada pada mata uang Euro, yaitu pada nilai standar deviasi mencapai angka 0,0267 dan 0,0638. Dari rata -rata yang dihasilkan, Dinar Emas mempunyai volatilitas paling tinggi yaitu sebesar 0,0408792 diikuti oleh Dolar Amerika sebesar 0,0408790. Euro memiliki volatilitas rata -rata paling rendah, hanya sebesar 0,04054 . 
Menurut hasil penelitian yang telah dilakukan, keputusan yang dapat diambil dari hipotesis yang telah disampaikan pada bab dua adalah:

1. Menolak Ho dan menerima $\mathrm{H}_{1}$. Mata uang Euro lebih baik hasilnya sebagai lindung nilai daripada mata uang Dolar Amerika.

2. Menolak Ho dan menerima $\mathrm{H}_{1}$. Mata uang Dolar Amerika lebih baik hasilnya sebagai lindung nilai daripada Dinar Emas.

3. Menerima Ho dan menolak $\mathrm{H}_{1}$. Mata uang Dolar Amerika dan mata uang Euro lebih stabil dibandingkan dengan Dinar Emas.

4. Menerima Ho dan menolak $\mathrm{H}_{1}$. Mata uang Dolar Amerika dan mata uang Euro lebih handal dibandingkan dengan Dinar Emas dalam Informasi Akuntansi.

\section{SIMPULAN}

Berdasarkan hasil yang didapat setelah mengolah, menguji, dan menganalisis data, ditarik kesimpulan sebagai berikut:

1. Berdasarkan hasil perhitungan volatilitas data return, rata -rata standar deviasi dari ketiga data dari yang paling tinggi hingga paling rendah adalah sebesar 0,0408792 (Dinar Emas), 0,0408790 (Dolar Amerika), dan 0,040540 (Euro). Artinya, dari perhitungan rata -rata 10 tahun yang mempunyai risiko keamanan terhadap investasi tertinggi adalah Dinar Emas, lalu Dolar Amerika, dan yang rendah risikonya adalah Euro.
2. Dari pengolahan data dengan jangka waktu 10 tahun (2003 2012), dapat diketahui bahwa pada tahun 2005, mata uang Euro merupakan mata uang dengan perubahan nilai dengan kecepatan tetap yaitu sebesar 0,029327 diikuti oleh Dolar Amerika 0,032527. Sedangkan Dinar Emas memiliki fluktuasi yang dramatis sebesar 0,032528 .

3. Dari pengolahan data dengan jangka waktu 10 tahun (2003 2012), dapat diketahui bahwa perhitungan volatilitas tahun 2007 menunjukkan fluktuasi nilai Dolar Amerika adalah yang tertinggi sebesar 0,034226. Dinar Emas menempati posisi kedua sebesar 0,034224 . Euro yang mempunyai volatilitas paling rendah sebesar 0,034211, ini menunjukkan bahwa Euro memiliki risiko keamanan perubahan nilai yang kecil.

4. Berdasarkan pernyataan hasil perhitungan standar deviasi, dapat diputuskan bahwa mata uang Euro merupakan mata uang yang paling stabil dan paling handal dalam Informasi Akuntansi diantara Dolar Amerika dan Dinar Emas. Karena Euro tetap stabil mempunyai volatilitas paling rendah dalam perhitungan tersebut. Perhitungan kestabilan, hanya bisa dilakukan jika data return bersifat homoskedastisitas.

5. Dinar Emas merupakan mata uang yang paling tidak stabil dibandingkan dengan Dolar Amerika dan Euro. Hal ini dibuktikan dengan perhitungan kestabilan ketiga jenis mata uang tersebut dalam kurs Dolar Amerika. Harga Dinar Emas tidak stabil disebabkan oleh jatuhnya suku bunga nyata, naiknya resiko premium saham AS, dan lainnya.

6. Karena perkembangan Dinar Emas yang belum maksimal, maka 
diantara mata uang Dolar Amerika dan Euro, Dinar Emas menjadi tidak stabil walaupun Dinar Emas mempunyai nilai intrinsik.

\section{DAFTAR PUSTAKA}

Ayub, Muhammad. 2009. Understanding Islamic Finance. Penerbit Gramedia Pustaka, Jakarta.

Ahmad, Rifki. 2009. "Sebuah Gambaran Dinamika Perekonomian" Review Kebijakan Luar Negeri dan Keamanan Amerika Serikat

Bappenas. 2012. "Macroeconomic \&

Financial Report". Jurnal Mingguan. 2 -6 Januari 2012.

----------. 2012, “Macroeconomic \&

Financial Report". Weekly Report.

6-10 Agustus 2012.

Barsamian, David dan Siok Han Liem. 2008. Menembus Batas (Beyond Boundaries) Damai Untuk Semesta. Yayasan Obor Indonesia, Jakarta.

Baswara, Satsya Yoga. 2012. "Analisis Nilai Hasil Investasi Deposito Rupiah, Deposito Dolar Amerika dan Dinar Emas Dengan Emas Sebagai Alat Ukur" Fakultas Ekonomika dan Bisnis Universitas Diponegoro.

Dewan Syariah Nasional (DSN). 2002. $\begin{array}{lrr}\text { Fatwa Dewan } & \text { Syariah } \\ \text { Nasional. } & \text { Majelis } & \text { Ulama } \\ \text { Indonesia, Jakarta. } & \end{array}$

Dijo, Sutan. 12 Maret 2010. Uang Komoditas dan Uang Fiat. http://ekonomi.kompasiana.com/bisn is/2010/03/17/uang-komoditas-danuang-fiat-95332.html. 4 Februari 2013.

Gerai Dinar. 4 Maret 2013. Grafik Prediksi.

http://geraidinar.com/index.php/grafi k-dinar. 4 Maret 2013.

Ghozali, Imam. 2011. Aplikasi Analisis Multivariate Dengan Program
IBM SPSS 19. Badan Penerbit Universitas Diponegoro, Semarang.

Hamidi, Luthfi. 2007. Gold Dinar. Senayan Abadi Publishing, Jakarta.

Hull, Jhon C. 2008. Fundamentals Of Future And Option Market. Sixth Edition .penerbit Pearson Prentice, New Jersey.

Indriyani, Epi dan Eeng Ahmad. 2007.

Ekonomi dan Akuntansi:

Membina Kompetensi Ekonomi.

Penerbit Grafindo Media Pratama, Bandung.

Iqbal, Muhaimin. 2008.'IMF dan Imperialisme Ekonomi". Jurnal Kajian Islam Al-Insan: Imperialisme. Nomor 1 Volume 3

Money. Gema Insani, Depok.

$\begin{array}{ll}\text { Terhadap } & \text { Inflasi } \\ \text { Dinar }\end{array}$

.http://www.geraidinar.com/index.ph p/using-joomla/extensions/com ponents/article/catagories/83-gdarticles/investasi/909-inflasiterhadap -dinar. 21 April 2013

- April 2013. Wag The Dog Harga Emas. http:// www.geraidinar.com/index.php/usin g-joomla/extensions/components/ article/catagories/83-gdarticles/investasi/1226-wag-the-dogharga-emas. 21 April 2013

Ikatan Akuntan Indonesia. 2007. SAK Per 1 September 2007. Penerbit Salemba Empat, Jakarta

Ismiyanti, Fitri dan Hendra Ima Sasmita. 2011. "Efektifitas Hedging, Kontrak Futures Komoditi Emas dengan Olein". Jurnal Manajemen Teori dan Terapan. Tahun 4 Nomor 2.

Jorion, Philippe. 2000. Value at Risk. Second Edition. McGrawHill, USA. Judokusumo, Suherdi. 2008. Pengantar Derivatif Dalam Moneter Internal. Penerbit Grasindo, Jakarta.

Kitco. April 2013. Monthly Gold Charts. http://www.kitco.com/charts/historic algold.html 
Lukman. April 2013. Harga Emas Berakhir Naik Dipicu Kekecewaan Pasar Atas Data Ekonomi AS. http://financeroll.co.id/news/1730/ha rga-emas-berakhir-naik-dipicukekecewaan-pasar-atas-dataekonomi-AS. 20 April 2013.

----------. April 2013. Untuk Pertama Kalinya Sejak 2000 Tahun Ini, Emas Akan Minus. http://financeroll.co.id/news/71787/u ntuk-pertama-kalinya-sejak-2000tahun-ini-emas-akan-minus. 20 April 2013.

Madura, Jeff. 2007. Pengantar Bisnis. Edisi Empat, Terjemahan. Penerbit Salemba Empat, Jakarta.

Mishkin, Frederic S. 2008. Ekonomi Uang, Perbankan, dan Pasar Keuangan. Edisi Sembilan, jilid 2. Penerbit Salemba Empat, Jakarta.

Nuning, Srie. 2008. "Penerapan Dinar Dirham Sebagai Mata Uang”. Jurnal Ekonomi dan Bisnis. Nomor VIII Vol. I

Oanda. April 2013. Historical Rates. http://www.oanda.com/currency/hist oricalrates. 18 April 2013.

Prudential Life Assurance. November 2012. Melindungi Nilai Mata Uang. Publikasi Dwi Bulanan. 22 Februari 2013.

Purwoto, Agus. 2007. Panduan Laboratorium Statistik Interferensial. Grasindo, Bandung.

Safarina, Dwi. 2008. "Mengukur Stabilitas Emas Sebagai Alternatif Nilai Tukar : Peluang dan Tantangan Bagi Perdagangan Internasional" Thesis Kajian Timur Tengah dan Islam, PSTTI Universitas Indonesia.

Saidi, Zaim. 2007. Ilusi Demokrasi: Kritik dan Otokritik Islam: Menyongsong Kembalinya Tata Kehidupan Islam Menurut Amal Madinah. Republika, Jakarta

Setyawan, Anton A. Oktober 2012. Melemahnya Ekonomi Amerika
VS Kebangkitan Euro. http:// . 31

Januari 2013.

Stighlith, Joseph E. 2006. Making Globalization Work. WW Norton and Company, New York.

Sugiarto dan Dergibson Siagian. 2000. Metode Statistika Untuk Bisnis \& Ekonomi. Gramedia Pustaka Utama, Jakarta.

Sugiyono. 2009. Statistika Untuk Penelitian. Alfabeta, Bandung.

Suharta, Tata. April 2013. Terbentur Level Ke 38,2\% XAU/USD Turun Lagi.

http://financeroll.co.id/technicalcomment/71824/terbentur-level-ke38-2-xauusd-turun-lagi. 20 April 2013.

Sulfa, Afif. 2009. "Modul Teori Akuntansi". Fakultas Ekonomi Universitas Mercu Buana.

Supranto, J. 2001. Statistik Teori \& Aplikasi. Jilid 1 edisi 6. Penerbit Erlangga, Jakarta.

Tanuwidjaja, William. 2009. Cerdas Investasi Emas. Media Pressindo, Yogyakarta.

Taufik, Mohamad dan Armiastho Adi Saputro. 2011. "Mata Uang Tunggal Euro : Implikasinya Terhadap Keuangan dan Bisnis Internasional" Paper Bisnis Internasional, Pasca Sarjana Institut Pertanian Bogor.

Triana, Rika. 2009. "Perbandingan Kestabilan dan Risiko Nilai Tukar Dolar AS, Euro, dan Dinar Ems Dalam Denominasi Rupiah Untuk Pengambilan Keputusan Hedging dan Investasi (Studi Kasus Pada PT. ABC)" Thesis Kajian Ilmu Tengah dan Islam, PSTTI Universitas Indonesia.

US. Department of Labour. 2013. Consumen Price Index. http://www.bls.gov. 18 April 2013.

Wahyudin, Nanang. April 2013. Dollar \& Yen Jatuh, Euro Rebound. http://www.seputarforex.com/berita/f orex/detail.php?nid=12439- 
tittle=dolar_yen_jatuh_euro_rebound . 18 April 2013.

Wakala Induk Nusantara. Oktober 2009.

Dinar Emas Dirham Perak Untuk

Kemakmuran dan Kejayaan

Bangsa.

http://www.wakalanusantara.com. 7 Januari 2013.

Widyarti, Heni. 2001. Modul Statistik Deskriptif. Politeknik Negeri Semarang, Semarang.

Wikipedia Ensiklopedia Bebas. Januari 2013. Dinar Emas. http://id.wikipedia.org/wiki/Dinar_E mas. 28 Februari 2013.

Wikipedia Ensiklopedia Bebas. Januari 2013. Dolar. http://id.wikipedia.org/wiki/Dolar. 22 Februari 2013.

Wikipedia Ensiklopedia Bebas. Januari 2013. Dolar Amerika Serikat.
http://id.wikipedia.org/wiki/Do

lar_Amerika_Serikat.

Februari 2013.

Wikipedia Ensiklopedia Bebas. April 2013. Indeks Harga Konsumen.

http://id.wikipedia.org/wiki/ind eks_harga_konsumen. 11 April 2013.

Wikipedia The Free Encyclopedia. April 2013. Reserve Currency. http://en.wikipedia.org/reserve _currency. 20 April 2013.

Winantyo, R., Sjamsul Arifin, dkk. 2008. Masyarakat Ekonomi ASEAN (MEA), 2015: Memperkuat Sinergi ASEAN di Tengah Kompetisi Global. Elex Media Komputindo, Jakarta 